\title{
The Demise of the Political Necessity Defense: Indirect Civil Disobedience and United States $v$. Schoon
}

\author{
James L. Cavallaro, Jr. $\dagger$
}

\section{INTRODUCTION}

The necessity defense allows a defendant who violated the letter of the law to be acquitted when she acted to further some greater good. At issue is not whether the defendant acted legally, but whether she acted morally. Because the necessity defense, like other affirmative defenses, requires a factual inquiry, its evaluation theoretically resides within the province of the jury. ${ }^{1}$

Perhaps due to judicial unwillingness to grant juries excessive discretion, however, courts have adopted strict evidentiary requirements that must be met before the necessity defense is presented to the jury. Judicial scrutiny appears to be particularly intense in cases of civil disobedience, when the defendants seek to imvoke the necessity defense to justify their otherwise illegal but politically motivated actions. Federal courts especially have been unwilling to apply the necessity defense to civil disobedience, adopting a strict four-prong test that has posed a virtually insurmountable obstacle to civil disobedients seeking to raise the defense. $^{2}$ As a result, federal courts have consistently excluded the defense as a matter of law, thereby preventing the jury from evaluating for itself the necessity of the defendant's civil disobedience.

Despite the infrequency with which the necessity defense is allowed in federal civil disobedience cases, this defense has been asserted successfully in several state courts, suggesting that federal courts have apphed necessity requirements more stringently than state courts. ${ }^{3}$ In United

$\dagger$ A.B. 1984, Harvard University; J.D. 1992, Boalt Hall School of Law, University of California, Berkeley; M.A. Candidate 1993, Latin American Studies, University of California, Berkeley; Orville Schell Fellow, Human Rights Watch, Washington, D.C., 1992-1993. Special thanks to Gary Gold for his contribution to the preparation of this Casenote.

1. "Where the accused asserts an affirmative defense, sanctioned by the law as justification or excuse for the criminal act charged, and offers some credible evidence in support thereof, the existence of such matter of defense is generally for the determination of the jury." 75 AM. JUR. 2D Trial § 829 (1991).

2. Although various courts have phrased the test differently, the elements discussed are fundamentally the same. See infra Part I.B.1.

3. See infra notes $59-62$ and accompanying text. 
States v. Schoon, ${ }^{4}$ the Ninth Circuit took a step beyond stringent application of the elements of the defense and created a per se rule barring the application of the necessity defense to cases of indirect civil disobedience-civil disobedience that challenges the legitimacy of a given act or policy through the violation of a law that is not itself challenged. ${ }^{5}$ Direct civil disobedience, by contrast, challenges a particular policy or law by contravening that same policy or law. ${ }^{6}$ The court's rationale for this new rule is not convincing. The Schoon court not only misapphed the elements of the necessity defense, but it also failed to weigh accurately the constitutional questions and policy considerations raised by adopting a rule which restricts a criminal defendant's fundamental riglit to present a defense.

Schoon inay provide a basis for courts wishimg to eliminate entirely claims of necessity by civil disobedients. First, the Schoon per se rule could be adopted by other circuits. Second, because the court's reasoning is as apphicable to direct disobedience as it is to mdirect civil disobedience, courts inay subsequently apply the Schoon holding to all cases of civil disobedience, indirect and direct.

Part I of this Casenote summarizes the elements of the common law defense of necessity as well as its applicability to cases of civil disobedience in the federal courts. Part II examines the facts of the Schoon case and the opimion of the district court. Part III summarizes the holding and the rationale of the Ninth Circuit opinion. Part IV analyzes the Ninth Circuit's reasoning, first arguing that the Schoon court misapplied the four-prong necessity test and drew an inappropriate distinction between direct and indirect civil disobedience. Part IV then argues that the court failed to address constitutional and pohcy concerns adequately before adopting its per se rule of exclusion. The final Section of Part IV suggests factors that the court should have examined in analyzing the necessity defense's application to imdirect civil disobedients, positing that these factors weigh against denying consideration of the necessity defense by juries.

\section{I}

\section{Evolution of the Necessity Defense}

\section{A. Criminal Law Origins of the Necessity Defense}

The necessity defense developed at early common law as a means of avoiding the injustice of pumishing a defendant who violated the letter of the law in order to prevent a greater evil than that which the law sought

\footnotetext{
4. 971 F.2d 193 (9th Cir.), cert. denied, 112 S. Ct. 2980 (1992).

5. Id. at 196 .

6. Id.
} 
to punish. ${ }^{7}$ The rationale underlying the defense is one of public policy: "[T] he law ought to proniote the achievenient of higher values at the expense of lesser values, and sometimes the greater good for society will be accomphished by violating the hiteral language of the criminal law."8 As a practical matter, the necessity defense recognizes that it is impossible to draft laws that take into account the infinite range of situations that may subsequently arise. ${ }^{9}$

Successful necessity defenses have been raised in a variety of cases. A doctor was justified in performing an otherwise-illegal abortion on a young rape victim because breaking the abortion law was necessary to prevent the greater physical and emotional trauma the victim would have experienced from carrying the child to term. ${ }^{10}$ A glauconia victim was justified in smoking marijuana in contravention of narcotics law because it was inedically necessary. ${ }^{11}$ The Model Penal Code suggests additional instances in which the necessity defense should be permitted: a defendant kills one person in order to save the hives of two or more; a mountain climber lost in a storm takes refuge in another's house and appropriates the homeowner's provisions; a druggist dispenses a drug without a prescription in an eniergency. ${ }^{12}$

The Suprenie Court has acknowledged the general apphicability of the necessity defense in criminal cases. In United States $v$. Bailey, ${ }^{13}$ the Court considered the necessity defense as apphed to defendants charged with prison escape. There the defendants alleged that prison conditions, including beatings, death threats, poor niedical treatment, and subjection to smoke froin intentionally set fires, necessitated their escape. ${ }^{14}$ However, the Court upheld the district court's rejection of the necessity

7. Englislı courts appear to lave recognized the principle of necessity as early as 1551 in Reniger v. Fogossa, 75 Eng. Rep. 1 (Ex. Cl. 1551). In Reniger, to avoid a perilous storm, defendant Fogossa docked his slip. By the strict terms of the statute, Fogossa sloould liave been required to forfeit the goods on board, yet lie successfully argued that necessity compelled an exception. Defendant's argument, accepted by the court, noted:

[A] man may break the words of the law, and yet not break the law itself . ... And therefore the words of the law ... will yield and give way to some acts and things done against the words of the same laws, and that is, where the words of them are broken to avoid greater inconvemences, or through necessity ...."

Id. at 29.

8. WAYne R. LaFave \& Austin W. Scott, JR., Criminal Law § 5.4(a), at 442 (2d ed. 1986).

9. See H.L.A. HART, THE CONCEPT of LAW 125 (1961) ("[H]uman legislators can lave no such knowledge of all the possible combinations of eircumstances which the future may bring.").

10. Rex v. Bourne, 1 L.J.K.B. 687 (1938).

11. See Robin Isenberg, Note, Medical Necessity as a Defense to Criminal Liability: Umited States v. Randall, 46 GEo. WASH. L. REV. 273 (1978) (discussing United States v. Randall, 104 Daily Wasl. L. Rep. 2249 (D.C. Super. Ct. Dec. 28, 1976)).

12. Model PenAl CodE $\S 3.02$ commentary at 9-10 (1985).

13. 444 U.S. 394 (1980).

14. Id. at 398 . 
defense, ${ }^{15}$ asserting that because prison escape is a continuing offense, a successful defense inust include proof that defendants sought to surrender to authorities once the conditions that created the necessity had abated. ${ }^{16}$ Although it ultimately rejected the necessity defense, the Court suggested that the defense could be valid under extreme circuinstances, and approvingly cited modern cases, the Model Penal Code, and a leading hornbook. ${ }^{17}$

\section{B. Civil Disobedience and the Necessity Defense}

For the purposes of this Casenote, civil disobedience "may be defined as open and purposeful lawbreaking that is politically motivated, and normally is accompanied by the actors' sense of moral indignation and duty."18 Theorists have argued that, for an act to be considered civil disobedience, the actor must accept whatever penalty is unposed for violation of the law. ${ }^{19}$ It is consistent with such a position, however, to argue that acceptance of the risk of punishment is sufficient for an actor's violation of law to constitute civil disobedience. ${ }^{20}$ If risk of purnshment suffices, then invoking the necessity defense would not undermine the actor's status as a civil disobedient.

As such, the necessity defense provides civil disobedients with a

15. The Court did not address the question of whether duress or necessity more appropriately characterized the defense set forth by the defendants, noting that recent cases have not distinguished between the two related defenses. Id. at 415 .

16. Id. at $412-13$.

17. Id. at $410-11$.

18. Sanford J. Rosen, Civil Disobedience and Other Such Techniques: Law Making Through Law Breaking, 37 GEO. WASH. L. REV. 435, 442 (1969).

19. See Steven M. Bauer \& Peter J. Eckerstrom, Note, The State Made Me Do It: The Applicability of the Necessity Defense to Civil Disobedience, 39 STAN. L. REv. 1173, 1189-94 (1987) (summarizing arguments for the proposition that civil disobedients should accept the punishment dictated by law).

At the conclusion of his trial for sedition in 1922, based on the publication of three articles he had written, Mohandas Gandhi requested that he be given the harshest sentence for his acts:

The only course open to you, the judge, is either to resign your post, and thus dissociate yourself from evil if you feel that the law you are called upon to administer is an evil and that im reality I am innocent, or to inflict on me the severest penalty if you believe that the system and the law you are assisting to admimister are good for the people of this country and that my activity is therefore injurious to the public weal.

Mohandas K. Gandhi, A Plea for the Severest Penalty upon His Conviction for Sedition, reprinted in The Law As Literature 95, 101 (Louis Blom-Cooper ed., 1961).

20. As one commentator noted:

The practitioner of civil disobedience must also undertake his acts of protest expecting that he will be subjected to whatever sanctions are provided to enforce the laws he violates im his protest. I do not mean that the civilly disobedient should not avail themselves of any legal defense, constitutional argument or appeal to the discretion of prosecutor, judge, jury or chief executive; nor should they forego efforts at politieal exoneration.

Rosen, supra note 18, at 455. Commentators have also recognized that "[o]ne might assert that the civil disobedient need only submit himself to the judgment of the courts to show that he accepts the social contract. Under this view, he is entirely within the parameters of philosophieally justified civil disobedience when he seeks to avert punishment by pleading necessity." Bauer \& Eckerstroin, supra note 19 , at 1191 . 
means of pleading a potentially complete defense to their criminal actions without forcing them to compromise their values and behefs. The civil disobedient claiming necessity can admit violating the law and thus focus the legal debate on the justness of a conviction under the circumstances. The necessity defense also allows civil disobedients to voice their reasons for lawbreaking in a public forum. Even if convicted, the civil disobedient will have enjoyed the opportunity to dehiver a message to an audience which may not otherwise have received it.

Civil disobedients frequently invoked the "choice of evils" defense in prosecutions stemming from Vietnam War protests, prompted by the opportumity to voice political opinions im their criminal trials. Imitially, such defendants argued unsuccessfully for a liberal construction of the jury's power to nullify, seeking jury instructions that expressly informed jurors that they had that power. ${ }^{21}$ Later, in United States $v$. Simpson, ${ }^{22}$ defendants raised the applicability of the necessity defense to civil disobedience. $^{23}$ In Simpson, the defendant surreptitiously entered the Selective Service office in San Jose, Califorma, and set fire to a drawer containing records, claiming that he did so im order to prevent further carnage in the Vietnam War. ${ }^{24}$ Althougli the court acknowledged the possibility that the necessity defense could justify some forms of civil disobedience, it rejected the defense on the facts, lolding that the defendant failed to establisli sufficient evidence to satisfy a basic element of the necessity test; namely, that there be a reasonable counection between a defendant's actions and prevention of the harm alleged. ${ }^{25}$

Subsequent cases in the federal appellate courts have similarly implied that the necessity defense was available to civil disobedients. ${ }^{26}$ However, federal appellate courts faced witl necessity claims im civil disobedience cases typically have found that defendants had failed to prove at least one eleinent of a four-prong necessity test, and therefore have not allowed the jury to liear and decide the necessity question. ${ }^{27}$

21. See United States v. Eberhardt, 417 F.2d 1009 (4th Cir. 1969), aff'g United States v. Berrigan, 283 F. Supp. 336 (D. Md. 1968), cert. denied, 397 U.S. 909 (1970); United States v. Moylan, 417 F.2d 1002 (4th Cir. 1969), aff'g Berrigan, cert. denied, 397 U.S. 910 (1970). For a discussion of a defendant's right to have the jury informed of its right to nullify, see United States $v$. Dougherty, 473 F.2d 1113, 1130-37 (D.C. Cir. 1972); id. at 1138-44 (Bazelon, J., concurring in part and dissenting in part).

22. 460 F.2d 515 (9th Cir. 1972).

23. Id. at $\mathbf{5 1 7}$ (the court discusses the necessity defense in terms of "jnstification").

24. Id. at 516 .

25. Id. at 518 .

26. "By excluding the political necessity defense on the ground that the defendants have not fulfilled its coinnion law elenients, courts have apparently accepted the notion that necessity can extend to civil disobedience." Bauer \& Eckerstronı, supra note 19, at 1183.

27. Id. at 1178 . 


\section{The Four-Prong Test: Legal Prerequisites to Bringing the Necessity Defense Before a Jury}

In United States v. Contento-Pachon, ${ }^{28}$ the Ninth Circuit reaffirmed the ordinary threshold required for placing a defense before the jury. ${ }^{29}$ With the viability of a duress defense at issue, the court wrote, "Factfinding is usually a function of the jury, and the trial court rarely rules on a defense as a matter of law."30 Under this general rule, to place a defense before the jury, a defendant need only present enough evidence so that a reasonable juror could find in her favor.

Yet with regard to the necessity defense, federal courts have erected a barrier of evidentiary requirements that must be met before defendants may present the defense to the jury. The Ninth Circuit has articulated these requirements as a four-prong test, requiring the defendant to present evidence sufficient to support a finding:

(1) that he [defendant] was faced with a choice of evils and chose the lesser evil; (2) that he acted to prevent imminent harm; (3) that he reasonably anticipated a causal relation between his conduct and the harm to be avoided; and (4) that there were no other legal alternatives to violating the law. ${ }^{31}$

Failure to meet the minimum evidentiary burden on any one of these

28. 723 F.2d 691 (9th Cir. 1984).

29. Id. at 695 .

30. Id. at 693 (citing Sandstrom v. Montana, 442 U.S. 510, 523 (1979)).

31. United States v. Aguilar, 883 F.2d 662, 693 (9th Cir. 1989) (citing United States v. Dorrell, 758 F.2d 427, 430-31 (9th Cir. 1985)), cert. denied, 111 S. Ct. 751 (1991).

Courts and commentators have stated the elements of the defense differently, yet the same factors are generally present. See, e.g., LAFAve \& ScOTT, supra notc 8, § 5.4(d). LaFave and Scott's summary of the defense identifies six elements. The first four address the balance of harms, considering (1) the harm avoided, (2) the harm done, (3) the intent to avoid harm, and (4) the relative value of the harm avoided. The fifth element considers the lack of legal alternatives and imminence requirements jointly. The sixth element requires that the actor not have been at fault in bringing about the harm to be averted. Because this final element is almost never relevant in the context of civil disobedience, it has not been discussed in the civil disobedience cases, and therefore is not considered in this Note.

In United States v. Cassidy, 616 F.2d 101 (4th Cir. 1979), the Fourth Circuit noted:

[E]ssential elements of the [necessity] defense are that defendants must have reasonably believed that their action was necessary to avoid an imminent threatened harm, that there are no other adequate means except those which were employed to avoid the threatened harm, and that a direct causal relationship may be reasonably anticipated between the action taken and the avoidance of the harm.

Id. at 102 .

The Tenth Circuit, in United States v. Seward, 687 F.2d 1270 (10th Cir. 1982), cert. denied, 459 U.S. 1147 (1983), described the elements of necessity as follows:

"The 'necessity defense' exonerates persons who commit a crime under the pressure of circumstances if the harm that would have resulted from comphance with the law would have signifieantly exceeded the harm actually resulting from the defendant's breach of the law.

"Successful use of the 'necessity defense' requires (a) that there is no third and legal alternative available, (b) that the harm to be prevented be imminent, and (c) that a direct, causal relationship be reasonably anticipated to exist between defendant's action and the avoidance of harm." 
four prongs precludes jury consideration of the necessity defense. ${ }^{32}$

Despite the court's intimation in Contento-Pachon that defenses generally should reach a jury, subsequent Ninth Circuit cases have strictly apphied the four-prong necessity test to civil disobedience defendants, restricting these defendants' ability to invoke the necessity defense. ${ }^{33}$ The Ninth Circuit's repeated refusal to allow the use of the necessity defense has been consistent with decisions of other federal appellate courts, which apparently fear the prospect of juries evaluating sensitive and emotional political claims. "Appellate courts appear to believe that the political necessity defense asks juries to participate in inferential acrobatics too daring to warrant the defense's submission" to tlie jury. ${ }^{34}$

\section{Applying the Four-Prong Test in Cases of Civil Disobedience}

Two of the four prongs in tlie necessity defense test, the balance of harns and imminence prongs, have rarely prevented defendants from invoking the defense. Pohtical protestors could expect to prevail on the balance of harms prong because dangers such as the harm of a foreign war or a nuclear liolocaust were generally considered to outweigh the harm of a trespass. ${ }^{35}$ Thus, commentators have noted that "it is usually an easy task for civil disobedients to slow that the liarm they souglit to avert outweiglis the harm of their protest activities."36

Id. at 1275 (quoting State v. Marley, 509 P.2d 1095, 1098 (Haw. 1973)).

Because a minimum showing inust be made on each of the elements of the necessity defense, appellate courts rejecting defendant's proffers have typically focused their analysis on one or two of the four prongs and have not addressed broader issues. Thus, in United States v. Montgomery, 772 F.2d 733 (11th Cir. 1985), the court stated: "In order to establish the justification defense of necessity, defendants inust show, among other things, that they had no reasonable alternative to violating the law, a chance both to refuse to do the criminal act and also avoid the threatened harm." Id. at 736.

Despite superficial distinctions, these and other standards have a great deal in common. As one commentator has noted:

[V]irtually all common law and statutory definitions include the following: (1) the actor has acted to avoid a significant evil; (2) there are no adequate legal ncans to escape the harm; and (3) the remedy is not disproportionate to the evil sought to be avoided. The statutes and case law in a number of jurisdictions include two additional requirements: the harm inust be imminent and the action taken nust be reasonably expected to avert the impending danger.

Laura J. Schulkind, Note, Applying the Necessity Defense to Civil Disobedience Cases, 64 N.Y.U. L. REV. 79, 82 (1989) (footnote oinitted).

32. Aguilar, 883 F.2d at 693 .

33. In United States v. Dorrell, 758 F.2d 427 (9th Cir. 1985), the court held that the defendant failed to meet the imininuun requireinent on two of the four prongs. Id. at 433 . Subsequently, in Aguilar, the court held that the defendants had failed to show an absence of legal alternatives. 883 F.2d at 693 .

34. Bauer \& Eckerstrom, supra note 19, at 1178.

35. "Courts generally recognize that the harms perceived by activists protesting nuclear weapons and power and United States foreign policy-nuclear holocaust, international law violations, torture, and murder-are far greater than those created by a trespass." Schulkind, supra note 31 , at 107 .

36. Bauer \& Eckerstrom, supra note 19, at 1182. 
Protestors also could expect to prevail on the imminence prong. ${ }^{37}$ Nevertheless, one scholar has argued that the imminence prong adds an undue restriction to the necessity defense because it is based on the flawed assumption that for an action to be necessary, the harm must be proximate. ${ }^{38}$ In some situations, by the time the harm is proximate the window of opportunity to avert that harm has passed. The problems inherent in these two prongs notwithstanding, most civil disobedience cases have been determined based on the remaining two prongs: the causal link requirement and the absence of legal alternatives requirement.

\section{a. The Causal Link Requirement}

The third element of the four-prong test, whether a causal link existed between the defendants' actions and the harm sought to be prevented, has figured prominently in the rejection of the necessity defense for civil disobedience. In United States $v$. Cassidy, ${ }^{39}$ a district court rejected the necessity claim of protestors who had thrown blood and ashes on the walls and ceiling of the Pentagon to protest the desigu and possession of nuclear weapons. The Fourth Circuit affirmed the district court's rejection of the defense, finding that defendants failed to prove a direct causal relationship between their actions and the avoidance of the harm protested. ${ }^{40}$ Similarly, in United States $v$. May, ${ }^{41}$ the Ninth Circuit upheld the district court's ruling that evidence presented by defendants who illegally entered a naval base to protest the Trident missile system had failed to estabhish a "reasonable behef that a direct consequence of their actions would be the termination of the Trident program."42

37. But see United States v. Aguilar, 883 F.2d 662 (9th Cir. 1989), cert. denied, 111 S. Ct. 751 (1991); United States v. Seward, 687 F.2d 1270 (10th Cir. 1982). The Aguilar court expressed doubt about "the sufficiency of the proffer to establish imminent harm," but decided the case on the legal alternatives prong. 883 F.2d at 693 n.28. In Seward, a political protest case, the Tenth Circuit questioned the imminence of the threatened harm and suggested that civil disobedience night never successfully raise the necessity defense. The Seward court noted:

The defense of necessity does not arise from a "choice" of several courses of action, it is instead based on a real eniergency. It can be asserted only by a defendant who was confronted with such a crisis as a personal danger, a crisis which did not permit a selection fron among several solutions, some of which did not involve criminal acts. It is obviously not a defense to charges arisimg from a typical protest.

687 F.2d at 1276.

38. "Since the lesser evils defense already requires that the actor engage in conduct only when necessary to avoid the harm, the imminence requirement is an inappropriate and unnecessary additional limitation." 2 Paul H. Robinson, Criminal LAW Defenses § 124(f)(1) (1984).

39. 616 F.2d 101 (4th Cir. 1979).

40. Id. at 102 .

41. 622 F.2d 1000 (9th Cir. 1980), cert. denied, 449 U.S. 984 (1980).

42. Id. at 1008; see also United States v. Lowe, 654 F.2d 562 (9th Cir. 1981). In Lowe, thc Ninth Circuit reinforced the May lolding by affirming the district court's refusal to admit any evidence pertaining to the necessity defense based upon the defendants' failure to satisfy the causal link requirenient. Id. at 567 .

May and Lowe both involved protests of the Trident inissile system. However, whereas in May 


\section{b. The Absence of Legal Alternatives Requirement}

Perhaps even more than the causal link requirement, federal courts' application of the absence of legal alternatives requirement has prevented civil disobedients from bringing their necessity claims to the jury. For example, in United States v. Quilty, ${ }^{43}$ the Seventh Circuit rehed on the legal alternatives prong to reject defendants' claim of necessity in a trespass on military property. The Quilty court reasoned that defendants could not resort to illegal behavior, as long as a "'reasonable legal alternative to violating the law" "existed, ${ }^{44}$ noting, "There are thousands of opportumities for the propagation of the anti-nuclear message: in the nation's electoral process; by speech on public streets, in parks, in auditoriums, in churches and lecture halls; and by the release of inforination to the media, to name only a few."45 In its holding, the Quilty court reiterated that the availability of these alternative means of expression precluded a successful necessity defense, regardless of the practicality or viability of resorting to these options. ${ }^{46}$

In United States v. Montgomery, ${ }^{47}$ the Eleventh Circuit upheld the district court's refusal to submit the necessity defense to the jury and rejected defendants' claims that " 'the norinal political processes have been rendered ineffective to meet the dangers created by nuclear arms build-up." "48 Similarly, in United States v. Dorrell, ${ }^{49}$ the Nimth Circuit rejected an antinuclear protestor's claim of necessity, reasoning that because Dorrell had "recourse to the pohitical process to redress his concerns regarding nuclear war," his trespass on a missile base could not be excused by necessity. ${ }^{50}$

Otlier cases specifically considered the defendant's recourse to the admimistrative process. In United States $v$. Richardson, ${ }^{51}$ defendants charged with conspiracy to smuggle laetrile into the United States sought to invoke the necessity defense, contending that importing the drug was

the court allowed the defendants to present evidence on necessity prior to rejecting the defense, 622 F.2d at 1008, the Lowe court rejected necessity as a matter of law without admitting the evidence supporting the defense, 654 F.2d at 566-67. The Lowe court held that the Ninth Circuit's determination in May that the necessity defense failed in the context of Trident missile protests precluded the admission of evidence on necessity for the Lowe defendants. Id. By refusing to examine the impact of the threat of nuclear war on the üdividual defendants in May and instead accepting the determination in Lowe as a matter of law, the Ninth Circuit paved the way for the Schoon holding that certaim types of stimuli can never justify illegal action.

43. 741 F.2d 1031 (7th Cir. 1984) (per curiam).

44. Id. at 1033 (quoting United States v. Bailey, 444 U.S. 394, 410 (1980)).

45. Id.

46. Id. at 1033-34.

47. 772 F.2d 733 (11th Cir. 1985).

48. Id. at 736 .

49. 758 F.2d 427 (9th Cir. 1985).

50. Id. at 432 .

51. 588 F.2d 1235 (9th Cir. 1978), cert. denied, 440 U.S. 947 (1979). 
necessary to fight cancer. ${ }^{52}$ The Ninth Circuit rejected this claim, holding that defendants had available legal ineans to alter the FDA's classification of the drug, and thus its import prohibition, and so could not argue necessity. ${ }^{53}$

In United States v. Aguilar, ${ }^{54}$ the Ninth Circuit rehed primarily on the availability of alternatives in the judicial system to reject a necessity defense brought by civil disobedients who violated immigration laws, claiming that their actions were necessary to protect refugees from war in Central America. ${ }^{55}$ The court upheld the district court's refusal to place necessity before the jury, finding that the defendants had failed to show the absence of other legal alternatives. ${ }^{56}$ The defendants argued that they had, in fact, used existing methods, including appeals and petitions to the Immigration and Naturalization Service to the extent that such ineans were viable. ${ }^{57}$ The court rejected these claims, noting that the defendants had not exhausted available legal alternatives since they did not "appeal to the judiciary to correct any alleged improprieties by the INS and the immigration courts."58

\section{The Necessity Defense Before Schoon}

In contrast with the federal courts' unwillingness to permit the necessity defense, civil disobedients in state courts have often invoked the defense and won acquittal. Defendants have successfully argued necessity in prosecutions based on protests against U.S. Central American pol-

52. Id. at 1238-39.

53. Id. at 1239 .

54. 883 F.2d 662 (9th Cir. 1989), cert. denied, 111 S. Ct. 751 (1991).

55. Id. at 667 .

56. Id. at 693.

57. Id. at 693-94.

58. Id. at 693. 

icy, ${ }^{59}$ nuclear power and weaponry, ${ }^{60}$ apartheid, ${ }^{61}$ and pohicies of the
CIA..$^{62}$

Prior to Schoon, and despite the consistent rejection of the necessity defense for civil disobedients by federal courts, commentators still believed that civil disobedients could successfully raise the defense. Two observers noted, "[A]lthough courts have generally excluded the pohtical necessity defense, their common law analysis makes it possible that future defendants can satisfy a reasoned interpretation of the defense's

59. See HUMAN RIGHTS AND PEACE LAw Docket: 1945-1991, at 63-78 (Ann F. Ginger \& Frank Cialone eds., 4th ed. 1991) [hereinafter PEACE LAW DOCKET] for discussion of the following cases: Colorado v. Bock, PL-174/68, PEACE LAw DockET, supra, at 68 (Colo. Mun. Ct. June 25, 1986) (defendants occupied Denver office of Senator Armstrong to protest U.S. policy in Central America; necessity defense permitted; jury acquitted defendants); Illinois v. Fish, PL-329/74, PEACE LAW DocKET, supra, at 74 (Ill. Cir. Ct. May 17, 1988) (defendants protested U.S. Central America policy at Army Reserve Training Center; necessity defense permitted; jury acquitted defendants); Illinois v. Jarka, PL-123/66, PEACE LAW DockET, supra, at 66 (Ill. Cir. Ct. Apr. 15, 1985) (defendants protested U.S. involvement in Central America at Grcat Lakes Naval Base; necessity defense permitted; jury acquitted defendants); Vermont v. Keller, PL-39/44, PEACE LAw DOCKET, supra, at 64-65 (Vt. Dist. Ct. Nov. 17, 1984) (defendants prosecuted for trespass based on sit-in in Senator's office to protest U.S. policy in Central America; necessity defense permitted; jury acquitted defendants).

60. See California v. Jeroine, PL-222/74, PeAce LAw Docket, supra note 59, at 74 (Cal. Mun. Ct. Oct. 1987) (defendants blocked main gate to nuclear weapons laboratory; arrested for traffic violation; Traffic Coinmissioner permitted necessity defense; prosecuting attorney moved to drop charges; motion granted); California v. Block, PL-21/63, PEACE LAw DockET, supra note 59, at 63 (Cal. Mun. Ct. Aug. 1979) (defendants demonstrated against nuclear power at nuclear power plant; charged with trespass and resisting arrest; judge permitted necessity defense; jury lrung; at new trial, judge indicated that he would permit necessity defense; prosecuting attorney dismissed the case); Massachusetts v. Schaeffer-Duffy, PL-426/78, PEACE LAW DOCKET, supra note 59, at 78 (Mass. Dist. Ct. Nov. 1, 1989) (defendants arrested for trespass at nuclear weapons facility; necessity defense permitted; testimony allowed on the threat posed by the MX missile, the failure of legal means to abate thrcat, and the effectiveness of civil disobedience; jury acquitted defendants); Michigan v. Heyer, PL-48/64, PEACE LAW Docket, supra note 59, at 64 (Mich. Dist. Ct. Apr. 9, 1984) (defendants blocked einployee aecess to cruise missile factory; necessity defense permitted; jury acquitted defendants); Washington v. Karon, PL-148/68, PEACE LAw DockET, supra note 59, at 68 (Wash. Dist. Ct. Dec. 10, 1985) (defendants blockaded government plntounum-uranium extraction facility; necessity defense permitted; prosecution moved to dismiss charges; motion granted).

61. See Chicago v. Streeter, PL-121/66, PeAce LAw Docket, supra note 59, at 66 (Ill. Mun. Ct. May 17, 1985) (defendants arrested for trespass at South African consulate; necessity defense permitted; jury acquitted defendants); Washington v. Bass, PL-219/73, PEACE LAW DocKET, supra note 59, at 73-74 (Wash. Dist. Ct. Nov. 9, 1987) (defendants staged sit-in at state capital in support of Soutl African divestment bill; arrested after refused to disperse; necessity defense permitted; jury acquitted defendants); Washington v. Heller, PL-151/69, PEACE LAW DocKET, supra note 59, at 69 (Wash. Mun. Ct. Aug. 7, 1985) (defendants protested apartheid; charged with trespass; necessity defense pernitted; jury instructed that prosecution had burden of proving absence of necessity; jury acquitted defendants).

62. See Colorado v. Keranen, PL-161/70, PEACE LAw DockeT, supra note 59, at 70 (Colo. County Ct. Apr. 17, 1986) (defendants arrested at denonstration while attenpting citizen's arrest of CIA recruiters; charged with attempted trespass and obstructing peace officer; invoked choice of evils defense; prosecution dropped charges); Massachusetts v. Carter, PL-187/72, PEACE LAW DockET, supra note 59, at 72 (Mass. Dist. Ct. Apr. 15, 1987) (defendants arrested for disorderly conduct, trespass, and disturbing school; necessity defense permitted; jury acquitted defendants). 
elements."63 They noted that success for a civil disobedient depended on the elements of the defense being "reasonably formulated" by the relevant court. ${ }^{64}$ Similarly, another commentator noted, "Judges who properly apply current legal norms ought to allow most civil disobedience defendants to raise the necessity defense." 65

Although as a practical matter, federal courts' stringent application of the test has made placing the defense before the jury a difficult task, the possibility of civil disobedience being excused through necessity remained theoretically open. Schoon, however, marks the Ninth Circuit's shift from demanding that strict requirements be met before allowing the necessity defense to banning outright an entire class of civil disobedients' right to raise the necessity defense.

\section{II \\ SCHOON-FACTS AND DISTRICT COURT OPINION}

On December 4, 1989, approximately 150 people assembled outside the federal building in Tucson, Arizona, to participate in a protest against U.S. pohicy in Central America ${ }^{66}$ Violence and repression in El Salvador had been imtensifying as the government there responded to an offensive by leftist rebels. Just two weeks before the Tucson protest, uniformed assassims, subsequently linked to the El Salvadoran government, murdered six promment Jesuit priests, their housekeeper, and her teenage daughter. ${ }^{67}$ The massacre was one of thousands of similar incidents perpetrated by "death squads"68 durmg El Salvador's civil war. ${ }^{69}$

The Tucson protests against the government's policy toward $\mathrm{El}$ Salvador ordinarily involved no more than a vigil outside a federal office

63. Bauer \& Eckerstrom, supra uote 19, at 1183.

64. Id. at 1178 .

65. Schulkind, supra note 31 , at $80-81$.

66. Transcript of Proceedings at 11-14, United States v. Bernick (D. Ariz. Mar. 14, 1990) (No. CR-90-20-TUC-WDB) [hereinafter Bernick Transcript].

67. El Salvador: The Jesuit Trial, An Observer's Report, News From AMERICAS WATCH, Dec. 13, 1991, at 1. Nine El Salvadoran military personnel, all but three of whom had received military training from the United States, some on U.S. soil, confessed to the killings in great detail. Two of the nine defendants were convicted by an El Salvadoran court. Id.

68. Americas Watch has explained the term "death squad" as follows:

Death squads generally are plainclothes uuits of the armed forces that avoid accountability by such means as using vehicles with smoked-glass windows and without numbered license plates. Death squad victims are often seized, interrogated, and tortured before being killed, their mutilated bodies being left by the sides of roads or in "body dumps" . . . . In other cases, death squad victims are gunned down in broad daylight on the street or in their offices, as if the squads were flaunting their impunity. Particularly in the early 1980s, death squads frequently claimed "credit" for their killings.

americas Watch, El Salvador's Decade of Terror: Human Rights Since the ASSASSINATION OF ARCHBISHOP ROMERO 21 (1991).

69. By late November 1989, the decade-long civil war in El Salvador had "claimed the lives of tens of thousands of civilians." AMERICAS WATCH, supra note 68, at 1. "[V]ictims of [death squad] units number[ed] in the thousands" in this period. Id. at 21. 
building. ${ }^{70}$ However, on the day in question, prompted by the escalation of violence in El Salvador, a group of thirty to forty protesters decided to bring their protest indoors. ${ }^{71}$ These protesters, including defendants Gregory Schoon, Raymond Kennon, Jr., and Patricia Manning, entered the Tucson IRS offices" and once inside, chanted, "Keep America's tax dollars out of El Salvador."73 After authorities ordered the protesters to disperse or face arrest, the defendants were arrested. ${ }^{74}$

Several of the defendants in the district court proceeding, including all three appellants to the Ninth Circuit, had soine knowledge of the conditions in El Salvador. Defendant Schoon testified at trial that he had worked for two years in Mexico with the poor and had assisted Central American refugees in the Umited States. ${ }^{75}$ Defendant Kennon had worked for nine years in a ministry for El Salvadorans in Tucson. ${ }^{76}$ Defendant Manning had lived in Central America for several years while completing her doctoral dissertation research and performing casework with Witness for Peace. ${ }^{77}$

These defendants sought to explain that they had petitioned their elected representatives to change U.S. policy towards El Salvador on various occasions ${ }^{78}$ but that these efforts liad been met with no positive response. ${ }^{79}$ Just five days after the killing of the Jesuit priests, in the

70. Telephone Interview with Patricia Manning, Defendant in United States v. Schoon (Sept. 29, 1992).

71. Id.

72. Judgment Order at 2, United States v. Bernick (D. Ariz. Mar. 23, 1990) (No. CR-90-20TUC-WDB) [hereinafter Bernick Judgment].

73. Appellant's Petition for Writ of Certiorari at 7, Manning v. United States (9th Cir.) (No. 91-8276), cert. denied, 112 S. Ct. 2980 (1992) [herenuafter Manning Petition].

74. United States v. Schoon, 971 F.2d 193, 195 (9th Cir.), cert. denied, 112 S. Ct. 2980 (1992).

75. Sentencings at 26, United States v. Bernick (D. Ariz. Apr. 4, 1990) (No. Cr-90-20-TUCWDB) (April 4, 1990) [hereinafter Bernick Sentencings] (statenient of defendant Schoon).

76. Id. at 8 (statement of defendant Kennon).

77. Bernick Transcript, supra note 66, at 186-87 (testimony of defendant Manning).

78. Defendant Manning testified that her efforts included the following:

Over the years I frequently inet with iny congressional officials, called their offices to explain niy concerns, written [sic] letters to them regarding the same, sent form letters and printed materials to them in an effort to urge them to help stop the flow of our tax dollars to torture, kill and terrorize civilians.

I have, via letter, telegram, telex, or other printed unaterial, and phone calls to the White House switchboard, communicated the same nessage to Presidents Reagan and Bush. ... .

Finally, I've also attempted to obtain media coverage of such foruns and public events, in accord with the public information function of the media.

Bernick Sentencings, supra note 75, at 13-14.

79. Defendant Fisk's testimony in this regard is typical of the frustrating response the defendants received when they sought to use legal neans to alter U.S. policy:

Five years ago, in a conversation with iny representative to Congress, Jim Kolbe, I inforned him that U.S. helicopter gun ships were killing everything in the countryside of El Salvador-1nen, women, children, grandmothers, horses, cows and chickens. He replied that the helicopter gun ships in El Salvador "are worth their weight in gold. We're fighting the Soviet Union down there, and some people are going to get hurt."

Bernick Sentencings, supra note 75, at 29-30 (Supp.). 
midst of public outcry for reevaluation of U.S. government policy of funding the El Salvadoran government, the House of Representatives rejected a proposal that would have held back thirty percent of the U.S. military aid for El Salvador until at least the following Marcl..$^{80}$ The government's intransigence on the foreign aid issue proved to be the last straw for inany protestors. ${ }^{81}$

The defendants contended that their actions were necessary to prevent continued U.S. support of the government in El Salvador and the bloodshed that this support would cause. ${ }^{82}$ Although the district court found that the defendants were sincere in their beliefs and were motivated by humanitarian concerns, ${ }^{83}$ it leld that the necessity defense was precluded as a inatter of law on the grounds that: (1) the requisite immediacy was lacking, (2) the actions taken by defendants would not abate the evil, and (3) other legal alternatives existed for defendants to pursue. $^{84}$

The trial court found the defendants guilty of obstructing activities in the Tucson IRS office and failing to coinply with a federal officer's lawful order. ${ }^{85}$ On appeal, the sole issue before the Ninth Circuit was the trial court's decision to reject the necessity defense as a inatter of law. ${ }^{86}$

\section{III}

\section{The Ninth Circuit Opinion}

The Ninth Circuit began its analysis by noting that atteinpts to invoke the necessity defense should be denied only when the "'offer of proof[] is insufficient as a natter of law to support the proffered

80. Robert Pear, House Rejects Curb on Salvador Aid, N.Y. Times, Nov. 21, 1989, at A14.

81. Defendant Manning described her motivation as including:

The violence unleashed by the Salvadoran military last Novelnber against the civilian population, using U.S. tax dollars and military advisors in violation of the rules of war, the Nuremberg principles and the charters of the O.A.S. and the U.N., et cetera. And the particularly grisly premeditated slayings of the six Jesuit priests, and housekeeper and daughter, by the Salvadoran security forces, was for me the decisive moment. The rationalization of their actions by our admimistration, and the refusal to cut off military aid in light of such actions, led thousands of U.S. citizens across the country-not just 19 of us here-to participate in protest demonstrations, and to ellgage in non-violent civil disobedience, with the hope of holding our government accountable through the courts, the only other branch of government available through which to remind our government of its own laws.

Bernick Sentencings, supra note 75 , at 15.

82. Defendants attempted to offer into evidence a videotape on conditions in El Salvador to establish both the imminence and the magnitude of the harm they sought to prevent. Defendants intended to provide testimony on the absence of legal alternatives and the causal relationship prongs. See Bernick Transcript, supra note 66, at 6-8 (Supp.) (statement of D. Jesse Smith, attorney for defendant Flagg).

83. Bernick Judgment, supra note 72 , at 1.

84. Schoon, 971 F.2d at 195.

85. Id.

86. Id. 
defense." "87 The Ninth Circuit concluded that in this case the district court had held the defendants' arguments inadequate on three of the four prongs of the necessity test. ${ }^{88}$

Although the court could have simply affirmed the district court's decision on the record below, it felt there was a "deeper, systemic reason for the complete absence of federal case law recognizing the necessity defense" in this context. ${ }^{89}$ The court reasoned that this absence was based largely on the distinction between indirect and direct civil disobedience. The court then distinguished between the two forms of political action, stating:

Indirect civil disobedience involves violating a law or interferimg with a government policy that is not, itself, the object of protest. Direct civil disobedience, on the other hand, involves protesting the existence of a law by breaking that law or by preventing the execution of that law in a specific instance in which a particularized harm would otherwise follow. ${ }^{90}$

The court recognized that although prior Ninth Circuit cases had consistently found the elements of the necessity defense lacking in instances of indirect civil disobedience, "we have never addressed specifically whether the defense is available in cases of indirect civil disobedience."91

The court concluded that "necessity can never be proved" in instances of indirect civil disobedience because three of the four prongs of the necessity test can never be met. ${ }^{92}$ First, a claim of indirect civil disobedience, the court reasoned, involves the protest of "the existence of [some] law or policy."93 The mere existence of law or policy, the court lield, can never constitute a legal harm. ${ }^{94}$ General harms that may result from the "targeted law or policy" cause injuries that are "too imsubstantial . . . to be legally cognizable."95 Therefore, any protest of a law or policy by indirect ineans must necessarily fail the balance of harms requirement of the necessity test. ${ }^{96}$

Second, the court noted that in "indirect civil disobedience against

87. Id. (quoting United States v. Dorrell, 758 F.2d 427, 430 (9th Cir. 1985)).

88. Id.

89. Id.

90. Id. at 196.

91. Id.

92. Id. at 197. The court's full conclusion allowed that indirect civil disobedients may act against an imminent harm:

Analysis of three of the necessity defense's four elements leads us to the conclusion that necessity can never be proved in a case of indirect civil disobedience. We do not rely upon the imminent harm prong of the defense because we beheve there can be indirect civil Id. disobedience cases in which the protested harm is imminent.

93. Id.

94. Id.

95. Id.

96. Id. at 198. 
congressional acts ... the [civil disobedient's behavior] alone is unlikely to abate the evil precisely because the action is indirect."97 The court therefore held that indirect civil disobedience can never be sufficiently likely to effectuate the result that is the object of the protest, and therefore fails the causal relationship prong. ${ }^{98}$

Finally, the court held that the necessity defense can never apply to indirect civil disobedience cases because "legal alternatives will never be deemed exhausted when the harm can be mitigated by congressional action." 99 This is so, the court reasoned, because lawful political activity designed to change congressional policy will always be a legal alternative to misconduct aimed at changing an existing law or policy. ${ }^{100}$ Further, the mere possibility that Congress will take action in response to lawful pohitical activity satisfies the reasonableness requirement implicit in the legal alternatives prong. ${ }^{101}$

In concluding its opmion, the court explained the policy rationales behind its decision. ${ }^{102}$ The court noted that the application of the fourprong test liad resulted uniformly in denials of the necessity defense in federal indirect civil disobedience cases. ${ }^{103} \mathrm{~A}$ black letter rule of exclusion, therefore, would offer the dual benefits of saving judicial resources and sending a less ambiguous inessage to prospective civil disobedients about their clrances of successfully invoking the defense at trial. ${ }^{104}$ Additionally, the proposed rule would spare courts from having to pass judgment on areas constitutionally delegated to other branches and would help to prevent the distortion of the necessity defense's original purposes. ${ }^{105}$ Finally, the rule would eliminate the temptation for courts to "sabotage[ ] the usually low threshold for getting a defense theory before the jury."106

Judge Fernandez, in a brief concurrence, agreed that the district court's rejection of the necessity defense in this case should be affirmed. However, Fernandez questioned the court's view that Ninth Circuit case law favored the majority's broad loolding. "[T] he law of this circuit," he wrote, "constrains ine froin saymg that the necessity defense is not available in these kinds of cases." 107

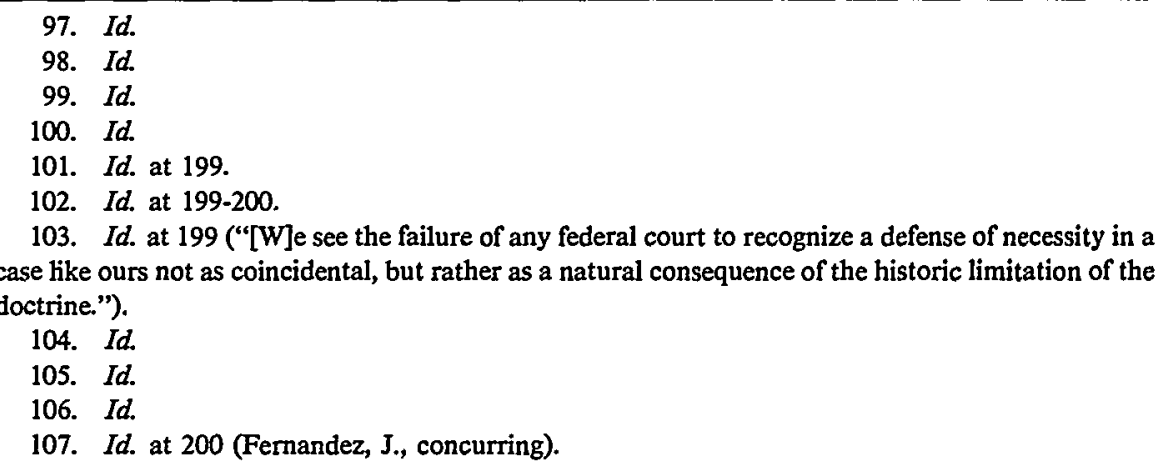




\section{IV}

ANALYSIS

The Ninth Circuit's opinion is a foray into judicial activism which is entirely unnecessary in order to affirm the conviction. ${ }^{108}$ Not only did the court consider and decide issues which were neither briefed nor argued by the parties, ${ }^{109}$ but the court's justifications for rewriting this area of law are not convincing. First, the court misapplied the fourprong test to a newly defined class of indirect civil disobedients. With regard to the balance of harms prong, the court mischaracterized the harm to be averted by indirect civil disobedients as the inere existence of a law or policy. The court went on to disregard the reasonableness requirement of the causal relation prong and to eviscerate the reasonableness inquiry as an element of the legal alternatives prong. These shifts in the court's approach to the four-prong test led the court to establish its per se rule excluding the necessity defense.

Second, the court's stated policy rationales fail to justify its distinction betwecn direct and indirect civil disobedience. Prior to the holding in Schoon, courts paid hittle attention to this distinction, either disregarding it entirely, or sinuply noting it in passing. ${ }^{10}$ This general unwillingness to attribute legal significance to the direct-indirect distinction was due primarily to the absence of any coherent rationale for treating the two types of disobedience differently witl regard to the necessity defense. The Schoon court also failed to provide such a rationale. Rather, its policy arguments for excluding the defense apply to both direct and indirect disobedience. The court's reasoning iniphes that the necessity defense could justify both kinds of disobedience. The court's policy rationales fail to convince the reader that the necessity defense ought to be precluded for either class of civil disobedience.

The inappropriateness of the Schoon decision is emphasized by the court's failure to balance constitutional arguments that weigh heavily in favor of allowing defendants to present their defenses to the jury and that are virtually iguored under the court's per se rule of exclusion. Moreover, the policy considerations behind botli the necessity defense and civil disobedience favor the application of a perimissive approach to civil

108. The court wrote, "[W]e could affirm substantially on those grounds relied upon by the district court . . . " 971 F.2d at 195.

109. Manning Petition, supra note 73 , at 8.

110. As Judge Ferguson noted in his Dorrell concurrence:

Soine, like Thoreau, chose to refrain from society's fundamental obligation to pay taxes for the common benefit in order to express their repugnance to a government that fostered slavery. Others, like the Reverend Martin Luther King, Jr., chose to counbat unjust laws directly by the nonviolent transgression of their terms. Regardless of the ineans chosen, those who practice civil disobedience do not challenge the rule of law or the incidents of an ordered society. Those engaged in civil disobedience acknowledge the validity of the pertinent law but find it personally offensive to their individual inoral judgments.

United States v. Dorrell, 758 F.2d 427, 435 (9th Cir. 1985) (Ferguson, J., concurring). 
disobedients' raising the defense. By failing to perform a thorough analysis of the relevant concerns involved in barring civil disobedients from raising the necessity defense, the court inappropriately denied an entire class of defendants the right to raise an important defense.

\section{A. The Misapplication of the Four-Prong Necessity Test}

\section{Mischaracterizing the Evils: The Balance of Harms Test}

The court held that an indirect civil disobedient's necessity defense will necessarily fail the balance of harms test because the harm sought to be prevented by these defendants can never be greater than the harm caused by their misconduct. ${ }^{11}$ In reaching this absolute decision, the court characterized the most immediate harm to be prevented in Schoon as the "existence of the government's El Salvador policy,"112 rather than as the imminent death and torture of hundreds and possibly thousands of El Salvadoran civilians, as the defendants themselves sought to argue at trial. By characterizing the harm to be prevented as the mere existence of a congressional policy, the court demed defendants the right to rely on the defense, irrespective of how the other three prongs were decided. ${ }^{113}$

\section{a. Standing and Indirect Civil Disobedience}

The Schoon court reasoned that because the defendants had only challenged the existence of a congressional policy, defendants could not assert a cognizable legal harm. ${ }^{114}$ The harm to defendants from the act they sought to prevent, in legal terms, amounted to nothing, which was necessarily less than the harm produced by violating the statute under which they were prosecuted.

By contrast, where an act operates on a civil disobedient directly, such that she must directly controvert it, the disobedient may suffer a cognizable legal harm. This harm, in turn, may be greater or less than the harm caused by violating the law, but it will not be zero, as in the case of the indirect civil disobedient. The court asserted that since standing requirements prevent an individual from challenging government poticy in the absence of a concrete injury, an indirect civil disobedient should not be permitted to use a " " "back door" attempt to attack gov-

111. Schoon, 971 F.2d at 198 ("If there is no cognizable harm to prevent, the harm resulting from criminal action taken for the purpose of securing the repeal of the law or policy necessarily outweighs any benefit of the action."). It is interesting to note that although the court found it "axiomatic" in all indirect civil disobedience cases that "the balance of harms necessarily ... disfavors any criminal action," id. at 197, the trial court, having heard the facts of this particular case, apparently did not see the balance so clearly, id. at 195 (of the four prongs, the protestors passed only the choice of evils prong at the district court level).

112. Id. at 198 (emphasis added).

113. Prior to Schoon, civil disobedient defendants had little problem satisfying this prong. See supra notes 35-36 and accompanying text.

114. Schoon, 971 F.2d at 197. 
ernment programs in a inanner foreclosed by [federal] standing requireinents." "115

Although on first impression the court's reasoning may appear sound, it suffers from a critical flaw. The court correctly recognized that a direct civil disobedient will personally suffer cognizable harm, and therefore should be allowed to invoke the necessity defense. The court then distinguished the indirect civil disobedient froin the direct, noting that the indirect civil disobedient is unlikely to face personal harm. What the court failed to see, however, is that personal harm, often necessary to establish standing, is not required in order to raise a defense to a criminal charge.

Thus, even assuming that the court's distinction was correct, and that direct civil disobedients face greater potential personal harm than indirect civil disobedients, it does not follow that the indirect civil disobedient should be barred froin invoking the necessity defense. There are ninumerable circumstances in which an individual inay lack standing to challenge a particular harm but would be able to present a successful defense to a criminal charge based on that harm. For instance, suppose that Bully attacks Victim in Samaritan's presence, and that Samaritan intervenes to protect Victim. Although Samaritan would not have standing to sue for injuries to Victim resulting froin Bully's assault, Samaritan could invoke a valid defense to a battery charge based on her defense of Victim. This result coinports with the logic behind both the doctrine of standing and the rules regulating defenses to criminal charges: while the foriner restricts federal court access to those hitigants with a personal stake in a given matter, the latter allows defendants to raise all defenses to which they are entitled.

Accordingly, while potential litigants are ordinarily not permitted to raise clainns of third persons, ${ }^{116}$ defendants are routinely allowed to raise

115. Id. (quoting United States v. Lowe, 654 F.2d 562, 566-67 (9th Cir. 1981)).

116. A litigant "geuerally must assert his own legal rights and interests, and cannot rest his clain to relief on the legal rights or interests of third parties." Warth v. Seldin, 422 U.S. 490, 499 (1975) (citations omitted). As the Supreme Court has explained:

The reason for this rule is twofold. The limitation "frees the Court not only from unnecessary pronouncement on coustitutional issues, but also from premature iuterpretations of statutes in areas where their constitutional application might be cloudy," and it assures the court that the issues before it will be concrete and sharply presented.

Secretary of State v. Joseph H. Muuson Co., 467 U.S. 947, 955 (1984) (quoting United States v. Raines, 362 U.S. 17, 22 (1960)).

The Supreme Court has recognized exceptions to this personal stake standing requiremeut. In Singleton v. Wulf, 428 U.S. 106 (1976), the Court wrote that it considered two primary elements in deciding whether a party will have standing to raise the claims of another. First, the litigant must show that her relationship to the party whose rights she wishes to represent is such that she "is fnlly, or very nearly, as effective a proponent of the right as the latter." Id. at 115. Second, she must show that the party whose interests she purports to represent is mipeded by "soine genuine obstacle" from asserting those rights himself. Id. at 116. 
the defense of others when arguing necessity. ${ }^{117}$ Legal harm for the purpose of determining standing is simply not coterminous with harm for the purpose of determining whether a defendant may raise a defense to a criminal charge. The Schoon court offers no rationale to support its characterization of the harms flowing from a government policy as per se insubstantial. More appropriately, the balancing of harms should be left to the jury.

\section{b. The Harm to Be Averted: U.S. Policy in El Salvador}

Consistent with this analysis, the Schoon court should have examined what harms, if any, arose from the U.S. government's policy toward El Salvador. The defendants sought to offer evidence at trial regarding human rights violations and war casualties in El Salvador. The defendants hoped to establish the role played by the U.S. government im supporting the groups responsible for the bulk of these abuses. ${ }^{118}$

At the time of the protests at issue in Schoon, casualties had increased im El Salvador as the government responded to the rebels' November offensive with counterattacks and repression. ${ }^{119}$ In addition to casualties of combat, "death squads" of the military government targeted and killed political opponents. ${ }^{120}$ The El Salvadoran military also relied frequently on torture in its efforts to prevail in the civil war. ${ }^{121}$

117. See LAFAve \& ScoTT, supra note 8, \$ 5.4(d), at 446. In presenting a necessity defense, the harm to be avoided "may be harm to the defendant himself, as where he takes another's food to save his own life; or it may be liarm to others, as where $A$, in no personal danger, intentionally runs his car over $B$ im order to avoid hitting $C$ and $D$." Id. (footnote omitted); see also United States v. Lopez, 662 F. Supp. 1083 (N.D. Cal. 1987) (necessity defense applied to a defendant who commits an otherwise criminal act to protect an unrelated third party), aff'd, 885 F.2d 1428 (9tll Cir. 1989), cert. denied, $110 \mathrm{~S}$. Ct. 748 (1990).

118. See supra note 82 .

119. The rise in hostilities triggered an intensified government response characterized by wholesale violations of the rules of war that resulted in the widespread killing of civilians. See ORgANIZATION OF AMERICAN STATES, ANNUAL REPORT OF THE INTER-AMERICAN COMMISSION ON HuMAN RIGHTS 1989-1990, at 142 (1990). The OAS Inter-American Commission on Human Rights, for example, noted reports of El Salvadoran Air Force use of incendiary bombs in densely populated civilian areas. Id. at 143. Otlier forms of official repression also intensified during the November offensive. See, e.g., AMERICAS WATCH, A YeAR OF RECKONING: El SALVADOR a DECADE AFTER THE ASSASSANation OF ARCHBISHOP ROMERo 9 (1990).

120. Amnesty International noted that 1989 saw "increased activity by so-called 'death squads,' whicl the goverument said were outside their control but whicli were widely alleged to be composed of police and military personnel operating both in uniform and in plain clothes." AMNESTY INTERNATIONAL USA, AMNESTY INTERNATIONAL REPORT 1989, at 122 (1990). In 1988 alone, there were over 152 deatl squad killings. See AMERICAS WATCH, supra note 68, at 17-18.

121. AMERICAS WATCH, supra note 68, at 18. As Americas Watch wrote:

The use of severe forms of torture also declined in the mid-1980s, only to reemerge toward the end of the decade. From 1980 to 1983 detainees were systematically tortured by all units of the security forces. The most frequent types of torture reported were severe beatings, deatli threats, clioking, electric shock, smothering witl a hood, drugging, sexual violence, submersion in water, burning with cigarettes, and mock executions. During the second lialf of 1984, there was a sliarp decline in the use of torture by the security forces, which stayed at that lower level for several years. . . . Then, in 1989, particularly after the 
Throughout El Salvador's decade-long civil war, U.S. aid facilitated the Salvadoran military's war effort. In the ten-year period from 1980 to 1989 , the United States provided more than $\$ 3.5$ billion $\mathrm{m}$ economic and military aid to El Salvador. ${ }^{122}$ The El Salvadoran government used much of the nearly $\$ 1$ billion im military aid in this period to purchase weapons, mcluding helicopters, planes, guns, and bullets used to kill thousands of combatants and civilians. ${ }^{123}$ Although the U.S. government officially contended that aid to El Salvador was conditioned on improvenients in El Salvador's human rights record, dollars flowed to the Central American nation throughout the decade regardless of the level of official repression. ${ }^{124}$

The Schoon court should have asked whether a reasonable juror could have beheved that the consequences of the contimued funding of the El Salvadoran military constituted a harm greater than that produced by defendants' acts in the Tucson federal building. Such an approach would have been consistent with at least one other court of appeals decision which evaluated the real world harms imvolved when characterizing the harm sought to be prevented by civil disobedients. In United States $v$. Quilty, ${ }^{125}$ while rejecting defendants' claim of necessity to justify an antinuclear protest, the Seventh Circuit characterized the harm the protesters sought to prevent as the threat of nuclear war rather than as the existence of U.S. nuclear weapons pohicy. ${ }^{126}$

When so characterized, this harm could hardly be considered a lesser evil than trespass. As the Quilty court wrote: "It is, of course, impossible to argue that nuclear war is not a nore serious harm than a

right-wing ARENA party won the presidential elections in March, human rights organizations detected a resurgence of inore drastic inethods of torture on the part of all Id. branches of the armed forces.

122. See id. at 119, 141 app. a. At no poimt after 1983 did U.S. funding fall below $\$ 325$ million-just $\$ 25$ million less than the average for the 1980-1989 period. Id. at 141 app. a.

123. Id. at 119. The Umited States' links to the abuses of the El Salvadoran government, however, may include more than financial assistance. According to one credible former death squad member, U.S. military involvement in the Salvadoran army's human rights abuses mcluded paying for some death squad operations and reviewing photocopies of arrest reports. Id. at 25-27.

124. The U.S. government often sought to establish a link between U.S. aid and improvement in the El Salvadoran government's human rights rccord. In the 1980 s, Congress implemented a certification process for human rights aid to El Salvador. Under the certification process, although Congress could not directly limit aid, the administration was required to certify improvements in the human rights situation in El Salvador to justify funding that country's military. As a result, the administration had a vested interest in finding such miprovements in order to legitimize continued support for the El Salvadoran government. See Cynthia J. ARnson, Crossroads: Congress, THE ReAGAN ADMINISTRATION, AND CENTRAL AMERICA 210 (1989). But instead of conditioning aid on actual improvements in the protection of human rights, the U.S. government was unore concerned with promoting the appearance of improvement in the El Salvadoran government's behavior, regardless of reality. See AMERICAS WATCH, supra note 68, at 117-37 (discussing the role of the United States in perpetuating abuses by the El Salvadoran government).

125. 741 F.2d 1031 (7th Cir. 1984) (per curiam).

126. Id. at 1033 . 
peaceful, if unlawful, anti-nuclear prayer demonstration at the Arsenal." 127 Had the Schoon court followed this approach, it would have evaluated the harm the defendants sought to prevent as a campaign of terror against civilians rather than as the mere existence of a congressional policy. The Schoon court's mischaracterization of the harm marks a sharp departure from the general rule in necessity cases that protection of others from death or serious mjury meets the "balance of harms" requirement. ${ }^{128}$

\section{Judging Defendants in Hindsight: The Causal Relationship Prong}

The Schoon decision also miscliaracterized the causal relationslip requirement $\mathrm{m}$ reaching its conclusion that indirect civil disobedience may never be causally connected to the targeted harm. ${ }^{129}$ The court merely asserted tliat mdirect civil disobedience, because it is indirect, is unlikely to bring about its intended result. ${ }^{130}$ Althougl it may be true tliat, as a class, direct civil disobedients will be more likely to effectuate pohicy change than mdirect civil disobedients, it does not follow tlat indirect civil disobedients will never be able to achieve their objectives. Thougli the court would not acknowledge it, well-orchestrated and publicized acts of indirect civil disobedience may, in some instances, aclieve civil disobedients' objectives.

More probleinatic was the court's failure to consider tlie reasonableness of the defendants' behefs, a practice which, prior to Schoon, the Nimth Circuit had considered an essential step in deciding tlie causal relationship prong. ${ }^{131}$ At the outset of the opinion, the court accurately set forth the Nimth Circuit test on the causal prong as an inquiry into whether the defendants "reasonably anticipated a direct causal relationship between their conduct and the harm to be averted."132 Nonetheless,

127. Id. (footnote ommitted).

128. See supra note 117 and accompanying text.

129. Commentators have argued that by requiring the nexus between the particular act of civil disobedience and termination of the challenged policy to be directly causal, courts havc misconstrued the purpose of the causal relationship prong. At common law, defendants were not required to show that their actions would avert the threatened harm beyond doubt. Rather, the court would evaluate the plausibility of the defendants' actions and would submit the issue to the jury provided that there was a reasonable causal relationship. Bauer \& Eckerstrom, supra note 19, at 1180-81 (citing Edward B. Arnolds \& Norman F. Garland, The Defense of Necessity in Criminal Law: The Right to Choose the Lesser Evil, 65 J. CRIM. L. \& CRIMINology 289, 293-97 (1974)).

130. Schoon, 971 F.2d at 198.

131. In United States v. Aguilar, 883 F.2d 662 (9th Cir. 1989), cert. denied, 111 S. Ct. 751 (1991), the court stated that the third prong of the necessity test required that the defendant "reasonably anticipated a causal relation between his conduct and the harm to be avoided." Id. at 693. The court in United States v. Dorrell, 758 F.2d 427 (9th Cir. 1985), noted that to make out a necessity defense, "the defendant must establish that he reasonably anticipated the existence of a direct causal relationship between his conduct and the harm to be averted." Id. at 431 (einphasis added) (citing United States v. Simpson, 460 F.2d 515, 518 (9th Cir. 1972)).

132. Schoon, 971 F.2d at 195. 
the court's brief discussion of this prong failed to address the defendants' reasonable anticipation of success. Instead, the court noted that the causal relationship requirement "requires a court to judge the likelihood that an alleged harm will be abated by the taking of illegal action."133 In addition to eliminating the actor's perspective, the court failed to place sufficient emphasis on the ex ante nature of the inquiry. ${ }^{134}$

The court should not examine, with hindsight, whether an act will bring about a certain result, but rather, whether an act could reasonably have been anticipated to do so before the fact. The court's failure to so analyze the Schoon protest leads it to the conclusion that the defendants failed to show a causal nexus. Had the court examined the reasonable expectations of the defendants, though, this determination likely would have been different.

The Schoon defendants believed that their actions, combined with those of others throughout the country, might inspire a congressional reevaluation of U.S. policy toward El Salvador. ${ }^{135}$ Because congressional votes on appropriations to Central American nations have often been close, the civil disobedient defendants may reasonably have beheved that their actions would influence enough legislators to shift the balance. Indeed, the defendants felt they possessed empirical evidence to support this behief. ${ }^{136}$

In October 1990, im response to public opinion and protest, Congress voted to witlihold fifty percent of the military aid to E1 Salvador pending imvestigation of the murders of the Jesuit priests. ${ }^{137}$ This figure represented the largest cut in American aid to El Salvador

133. Id. at 198.

134. One observer has written: "[T]he reasonableness of a defendant's belief must be measured ex ante. ... [J]udicial hindsight will discourage the civil disobedient from acting upon what appears to be a reasonable behief at the moment the action is required because her reasonableness will not shield her from hability." Schulkind, supra note 31, at 90-91 (footnotes omitted). The disregard for the reasonableness element also undermines the court's conclusion regarding the likelihood that indirect civil disobedience will effectuate its goals. Even if the inquiry is performed from the court's perspective in hindsight, an accurate application of the causation requirement would not require that the defendant show his actions were likely to bring about the iutended result. Instead, the defendant need only show that his actions were reasonably likely to do so.

For example, suppose Hero hears the cries of a drowning baby on his neighbor's property. To save the child, Hero inust destroy his neighbor's fence and trespass onto her property. Also, suppose that Hero knows that the chances of saving the baby are minimal because Hero cannot swim. Requiring that the illegal acts (here trespass and destruction of property) be likely to effectuate the desired end (saving the baby) would render Hero ineligible for the necessity defense. Yet hardly a soul would deny that his actions in attempting to save the child are reasonable, and therefore reasonably likely to effectuate his aim. What inakes them so is the relationship between the magnitude of the harm caused and that to be prevented. By not addressing this relationship in the causation prong, the court facilitates the rejection of the defense for indircet civil disobedients.

135. See infra text accoinpanying note 140 .

136. One defendant, for example, testified that a sit-m at Senator Kerry's office resulted in the Senator changing his position on El Salvador. Bernick Transcript, supra note 66, at 200 (testimony of defendant Manning).

137. See AMERICAS WATCH, supra note 68 , at 15 . 
since the onset of that nation's civil war. ${ }^{138}$ Without doubt, the killing of the Jesuit priests, the event that triggered the Schoon protests, profoundly affected the congressional vote in October of $1990 .{ }^{139}$

In retrospect, the Schoon defendants may have helped produce a change in U.S. policy, a change which saved lives. It appears tenable that the defendants' actions might have becn reasonably anticipated to effect their goal-a change in U.S. policy toward El Salvador. As one defendant, Carolyn Trowbridge, sought to explain at trial:

When we planned this action, $\mathrm{m}$ going to the Internal Revenue Office as a peaceful, non-violent act of civil resistance, we felt, again, that this was part of a chain of events that would lead directly to the Congress and the President of the United States. These are the lessons that we learned in the 60 s and 70 s, in dealing with that governmental policy, that individual people, acting in conscience, joining together, building larger movements, can affect [at this point, testimony was interrupted by a prosecution objection which was sustained]. ${ }^{140}$

Defendant Trowbridge's testimony raises another difficulty with the Schoon approach to causation. The court's analysis requires direct causation and imphicitly refuses to give credence to the possibility that the defendant set in motion a chain of events likely to produce her goal. Should a causal chain suffice, or must the causation be direct? Again, returning to the test's language-an examination of the reasonable expectations of the defendants-helps us answer this question. If a defendant's actions may help to effectuate an eventual change in governnient policy that will save hives, the court should allow the jury to consider whether her conduct could reasonably have been anticipated to effectuate her goals. Indeed, the subsequent course of events, including the congressional cuts in support for the El Salvadoran government, indicates that the defendants' behef im a causal relationship between their actions and a potential policy change was not unreasonable.

In a Vermont case arising from circumstances similar to those in Schoon, defendants protested U.S. policy toward El Salvador and Nicaragua by occupying Senator Robert Stafford's office. ${ }^{141}$ At trial, the defendants sought to invoke the necessity defense, presenting evidence of

138. Id.

139. The importance of the massacre on U.S. policy was summarized in Congressional Quarterly as follows: "More than any other factor, the murder that night of six Jesuit priests, along with their two housekeepers, seemed to weigh on the minds of senators as they approved the Dodd-Leahy amendment [reducing aid to El Salvador] to the foreign aid appropriations bill . . . " Carroll J. Doherty, Aid to El Salvador Slashed, CoNG. Q., Oct. 27, 1990, at 3628.

140. Bernick Transcript, supra note 66 , at $153-54$ (testimony of defendant Trowbridge).

141. Schulkind, supra note 31, at 93, 100 (discussing State v. Keller, No. 1372-4-84 (Vt. Dist. Ct. Nov. 17, 1984)). The Keller case is reported as Vermont v. Keller, PL-39/64, PeAce LAW DockeT, supra note 59, at 64-65. 
torture in El Salvador and illegal and unconstitutional actions by the executive branch. ${ }^{142}$ Numerous witnesses were allowed to testify to the conditions in El Salvador and Nicaragua, as well as to the history of U.S. protest movements and to the role of private citizens in formulating U.S. foreign policy. ${ }^{143}$ The defendants further established that their actions coincided with an upcoming congressional vote and were part of a strategy of similar actions nationwide. ${ }^{144}$ The defendants successfully demonstrated, therefore, "a strict causal nexus between the action taken and the harm to be averted."145

Even if the Ninth Circuit considered the facts in Schoon, or even Keller, insufficient to meet the requireinents of the causal relation prong, it would still be possible to imagine a case in which the actions of indirect civil disobedients could satisfy the causation requirement. For example, had the Schoon defendants blocked the aisles of Congress, thus impeding Representatives and Senators froin actually voting to send aid to El Salvador, the causal link prong would undoubtedly have been met. However, under the per se rule adopted in Schoon, a court could never find that the causation requirenent had been inet by indirect civil disobedience, even if this were clear from the facts.

\section{Requiring the Unreasonable: The No Legal Alternatives Requirement}

The Schoon court stated that "legal alternatives will never be deemed exhausted when the harm can be mitigated by congressional action,"146 adding that the possibility of exercising legal means to alter congressional pohicy will always exist for indirect civil disobedients. ${ }^{147}$ Thus, according to the court, an indirect civil disobedient seeking to invoke the necessity defense will always fail the legal alternatives prong because a legal means to change a law or policy will always exist.

142. See Schulkind, supra note 31 , at 100 (discussing Defendants' Trial Brief at 4, State v. Keller, No. 1372-4-84 (Vt. Dist. Ct. Nov. 17, 1984)).

143. In Keller, the following witnesses were permitted to testify: Sonya Hernández (on political violence in El Salvador); Janet Shenk (on human rights in El Salvador); Phil Bourgois (on Salvadoran refugees); Shaila Sherwin (on refugees); David Rosenberg (on United States-backed Contra war in Nicaragua); David McMichael (on Contra aid); Richard Garfield (on health programs of the Nicaraguan governinent); John Stockwell (on CIA activities); Howard Zinn (on the history of U.S. protest movements); Matthew Countryınan (on U.S. military aid to Central America); Gladys Sánchez (on governinental repression of churches in El Salvador); Richard Falk, Ramsey Clark (on citizens' role in U.S. foreign policy). See PEACE LAw DockET, supra note 59, at 6465 (discussing the Keller case).

144. See Schulkind, supra note 31, at 104-05 (discussing Defendants' Trial Brief at 24, State v. Keller, No. 1372-4-84 (Vt. Dist. Ct. Nov. 17, 1984)).

145. Id. at 104.

146. Schoon, 971 F.2d at 198.

147. The court wrote: "[T]he harm indirect civil disobedience aims to prevent is the continued existence of a law or policy. Because congressional action can always mitigate this 'harm,' lawful politieal activity to spur such action will always be a legal alternative." Id. 
In reaching its holding on legal alternatives, the Schoon court broadly interpreted Dorrell, in which the Ninth Circuit rejected an antinuclear protestor's necessity defense on the grounds that other reasonable legal alternatives existed. ${ }^{148}$ According to Schoon, "Without expressly saying so, Dorrell decided that petitioning Congress to change a policy is always a legal alternative in such cases, regardless of the likelihood of the plea's success." 149 But it is not clear that the Dorrell court reached such an expansive conclusion. Although language in Dorrell imphies that civil disobedients nay always have the opporturnity to petition Congress, the court did not exphicitly preclude the necessity defense in all cases where petitioning Congress was a theoretical option. ${ }^{150}$

The Schoon court's broad reading of Dorrell either finds petitioning Congress to be a viable legal alternative, and thus reasonable, or it simply eliminates any consideration of reasonableness, express or implied, from this prong. Outright elimination, though, contravenes prior case law, which consistently included reasonableness in the legal alternatives inquiry. As the Supreme Court stated in Bailey, only "if there was a reasonable, legal alternative to violating the law, 'a chance both to refuse to do the criminal act and also to avoid the threatened harm,' the defense[] will fail."151

Nonetheless, it appears that the court's intent was simply to remove reasonableness from the inquiry in indirect civil disobedience cases. Indeed, the court argued that the inere possibility of petitioning Congress, no matter how unlikely to produce the desired result or how grave the harm to be averted, provided sufficient grounds to preclude the necessity defense. ${ }^{152}$ This reasoning is wholly inconsistent with the logic behind the necessity defense. The defense withholds criminal sanctions for the defendant who acted reasonably by violating the law when doing so was the inore reasonable course of action. The Schoon court limited its apphication of this reasoning to indirect civil disobedience; were it to apply this logic uniformly, the necessity defense would perish. For no inatter what the choice of evils presented to an actor, some legal alternative will always exist.

Although the result the court reaches with regard to the reasonableness of petitioning Congress is consistent with prior case law, the Schoon court's reasoning is not sufficiently persuasive, especially since the rule it

148. United States v. Dorrell, 758 F.2d 427, 431 (9th Cir. 1985) (citing United States v. Bailey, 444 U.S. 394,410 (1980)).

149. Schoon, 971 F.2d at 199.

150. Dorrell, 758 F.2d at 432 .

151. United States v. Bailey, 444 U.S. 394, 410 (1980) (emphasis added) (quoting WAYNE R. LaFave \& Austin W. Scotr, Jr., Criminal Law 379 (1st ed. 1972)). The Ninth Circuit in United States v. Aguilar, 883 F.2d 662 (9th Cir. 1989), cert. denied, 111 S. Ct. 751 (1991), phrased the test without reference to the term "reasonable." See id. at 693.

152. Schoon, 971 F.2d at $198-99$. 
establishes, unlike the looldings in prior federal cases, constitutes an outriglit ban on the presentation of the necessity defense for an entire class of defendants. The Nintl Circuit slould have examined in closer detail whether it is always reasonable to petition Congress before engaging in indirect civil disobedience. Its conclusory analysis is not appropriate in the context of appellate review designed to establisl a new per se rule. Had the court reexamined the reasonableness of petitioning Congress, rather than relying on the isolated conclusions of a few prior cases, it might well liave reaclied a different result.

Frequently, legal alternatives, including the petitioning of Congress, will not be viable options and, therefore, may not be reasonable. For example, in a case in whicll prompt governmental action is required to avert liarm, inaking use of legal channels inay be unreasonably time consuming. Alternatively, it may be necessary to take actions calculated to liasten the congressional process. Sucl1 action is particularly necessary when every day delayed means more suffering or death, as it does in the case of military assistance to countries witl consistent patterns of gross violations of liuman riglits.

This Casenote argues that it is not always reasonable for courts to require an individual whose moral convictions are offended by his government's policy to patiently petition the imstitution that has produced the unjust policy. If, as the Schoon defendants asserted, Congress funded the training and equipping of a repressive foreign government's security forces, thereby facilitating the wholesale slaughter of civilians, concerned citizens slould not liave been limited to legal but generally ineffectual acts sucl as writing letters to their congressional representatives. Instead, they sliould be permitted to engage in nonviolent civil disobedience aimed at altermg the policy they consider unjust, provided that they convince a jury that their unlawful actions were necessary.

\section{B. Policy Rationales}

The Schoon court proposed a series of policy rationales to support its per se rule of exclusion of the necessity defense for indirect civil disobedience. These policy justifications, lowever, fail on two levels. First, they do not explain wly indirect civil disobedience ouglit to receive different legal treatment thian direct civil disobedience. Second, they are not convincing bases for precluding any kind of civil disobedients from raising the necessity defense. The untenable nature of the indirect-direct distinction is related to the general failure of the court's pohicy arguinents: botli are the result of the court's contempt for application of the defense to any kind of civil disobedience. This Section first addresses the incolierence of the indirect-direct distinction with regard to each policy rationale, and then considers the persuasiveness of these rationales as 
applied to civil disobedience generally. In the Conclusion, I return to the court's lostility toward civil disobedients raising claims of necessity.

The court first offers judicial economy as a reason for barring the necessity defense for imdirect civil disobedients. However, conservation of judicial resources would be more efficiently realized were the court to adopt a blanket rule precluding the necessity defense in all civil disobedience cases. Defendants arguing necessity as a justification for their acts of direct civil disobedience liave fared no better in the Nintl Circuit than those involved in indirect political conduct. ${ }^{153}$ If repeated failure were a suitable basis for the per se rule, the court should have simply rejected the necessity defense in all civil disobedience cases, witlout crafting the inappropriate direct-mdirect distimction. ${ }^{154}$ Such a rule, of course, would provide even greater savings of judicial resources.

The judicial economy argument, however, cannot justify precluding the necessity defense for all forms of civil disobedience. Of course the preclusion of any affirmative defense for any class of defendants brings with it significant savings of judicial resources, since most defendants fail to establish such defenses. Yet ours is a system in which defendants are permitted to raise defenses, even unlikely defenses, and argue them to the jury. This is, after all, the business of courts: to distimguish between valid and invalid claims on an individualized basis. There are limits to judicial resources, and for this reason, among others, defenses nnay not be raised unless a minimum thresliold has been met. However, as the Nintl Circuit and the Supreme Court have recognized, the threshold for presentation of defenses to the jury is quite low. ${ }^{15 s}$ The prospect of judicial economy offered by the elimination of a potential defense for a particular class of defendants does not provide a sufficient basis for overriding the policy in favor of allowing the accused to present all defenses available to her.

Next, the court argues that the creation of the per se rule of exclusion is driven by a desire to allow potential hitigants to assess more accurately their chances of successfully presenting a necessity defense. ${ }^{156}$ But again, exclusion of all civil disobedience cases would lave been the more accurate rule. The consistent failure of defendants to convince courts to accept the defense in both indirect and direct civil disobedience cases

153. See, e.g., United States v. Aguilar, 883 F.2d. 662 (9th Cir. 1989), cert. denied, 111 S. Ct. 751 (1991); United States v. Richardson, 588 F.2d 1235 (1978).

154. One night argue that the court, in opting to create a per se rule excluding the necessity defense only for indirect and not for direct civil disobedience, exercised judicial restraint. However, the court departed from judicial restraint by refusing to sinply affirm the judgment of the district court; there was no need to create a per se rule of any type. See supra notes 108-09 and acconipanying text.

155. See supra text accompanying notes $28-30$.

156. Schoon, 971 F.2d at 199. 
should have moved the court to adopt a blanket rule for both types of cases.

More to the point, the court's concern for accurate assessment of the risks of litigation by civil disobedients does not ring true. As a practical matter, civil disobedients are not likely to cease their unlawful behavior in light of the Schoon opinion. Indeed, the risk of conviction would exist even if the defense were still available. As discussed earher, accepting this risk of conviction and the legal consequences that follow are essential elemnents of civil disobedience. ${ }^{157}$ Rather than clarify tlie boundaries of legal action for civil disobedients, the court's per se rule changes thein. While the new rule nay be more clear, it does not benefit civil disobedients. As between a slim cliance and no chance of acquittal, a civil disobedient defendant would almost certainly prefer the foriner.

Elimination of the risk of judicial intrusion into the realm constitutionally assigned to other branches of government serves as another of the court's policy rationales. Yet this, too, is as applicable to direct civil disobedience as it is to indirect civil disobedience. To the extent that some cases of direct civil disobedience merit presentation to the factfinder and otlers do not, a court facing a necessity defense in this context would be asked to pass judgment on the actions of the other branches. ${ }^{158}$

Moreover, the court's fear of excessive judicial intrusion into the realm constitutionally assigned to other government branclies is unfounded. Necessity defendants do not ask courts to pass judgment on the other branclies. ${ }^{159}$ Indeed, the acquittal of a civil disobedient who successfully raises a necessity defense may not even affect congressional or administration policy. Sucli an acquittal inay, by itself, have no greater chance of undermining the policy in question than a single successful self-defense claim has of undermining laws criminalizing loonicide.

What should be of greater concern to the court than intruding into the realm of other government branches is the possibility of foreclosing a valid defense to criminal defendants merely because some minimal evalu-

157. See supra text accompanying notes 19-20.

158. Here, as with the court's other policy rationales, precluding all civil disobedients from raising the uecessity defense is as consistent with the court's rationales as allowing them all to raise the defense. The court fails to address the question of which of these two options is preferable. As I argue in the next Section, this question can only be adequately examined by considering the constitutional and policy conccrns behind the uecessity defense, civil disobedience, and the intersection of the two. The point here in showing that the court's rationales apply equally to both types of civil disobedience is that the distinction it draws is unwarranted. As a result, in order to address the question of the apphicability of the necessity defeuse to indirect civil disobedience, one must consider the applicability of the defense to civil disobedience generally. This inquiry, in turn, requires that one look at the broader policy questions taken up in the next section.

159. Even if the necessity defense required courts to engage in constitutional adjudication, this would hardly constitute a valid basis for shrinking from this duty. 
ation of the reasonableness of their claims is involved. Judicial deference in this context has the effect of affirming the justness of congressional and administrative policies, and thereby facilitating the conviction of defendants without any judicial examination of the challenged policy. The Schoon court effectively abdicates the proper role of the judiciary. The fact that civil disobedients require courts to examine pohitical questions with greater frequency than they must with other defendants cannot constitute a valid basis for depriving these defendants of the opportunity to have their claims heard.

A final proposed benefit of the per se rule is that it will prevent courts from "sabotag[ing] the usually low threshold for getting a defense theory before the jury as a means of keeping the necessity defense from the jury."160 Of course, if the goal were to wipe out judicial sabotage in the realm of civil disobedience, a flat out ban on the necessity defense for civil disobedients should be the rule. As indicated with regard to the other pohicy rationales, courts have strained to construe the elements of the defense against direct and indirect civil disobedients as alike.

More troubling, though, is the court's remedy for the judicial sabotage it detects. That remedy, exclusion of one class of political necessity cases, fails to address the problem directly. If cases of pohitically motivated civil disobedience are eligible for the necessity defense, then courts should fairly apply the relevant law-whether or not it involves rather low thresholds for the presentation of evidence to the jury. That courts have had difficulty in applying the necessity defense is no more valid a basis for rejecting it than would be the exclusion of all self-defense claims were courts to experience difficulties with defendants raising this claim. In our system, judicial ease generally does not outweigh procedural fairness to defendants when individual rights are at issue.

\section{Additional Considerations}

\section{The Constitutional Right to Present a Necessity Defense}

The right to present an adequate defense is safeguarded by the Fifth and Fourteentll Amendments. ${ }^{161}$ Where a civil disobedient has a right to a jury trial, ${ }^{162}$ the guarantees of the Sixth Amendment also play a crucial

160. Schoon, 971 F.2d at 199 (citing Bauer \& Eckerstroln, supra note 19, at 1178-79; Schulkind, supra note 31 , at $85-89$ ).

161. See, e.g., Chambers v. Mississippi, 410 U.S. 284, 302 (1973) (defendant's Fourteenth Amendinent due process rights were violated by court's refusal to allow him to cross-exainine his own hostile witness or to present three key witnesses); Webb v. Texas, 409 U.S. 95, 98 (1972) (per curiam) (judge's threatening remarks to defendant effectively drove hin froin the witness stand, thereby violating his Fourteenth Amendment due process right to present witnesses); Washington v. Texas, 388 U.S. 14, 17-18, 22-23 (1967) (precluding a potential defense witness because he was charged as an accoinplice violated defendant's Sixth Amendment right to compulsory process, incorporated via the Fourteenth Amendinent's Due Process Clause).

162. Since the charges against the Schoon defendants were not sufficiently severe to require a 
role. As the Minnesota Supreme Court recently noted, it is "fundamental that criminal defendants have a due process right to explain their conduct to a jury."163 Although the legislature and the courts have the power to define and limit defenses, they must exercise this power within the limits traced by the Constitution.

Even before the adoption of Schoon's per se rule of exclusion, commentators had argued that the strict interpretation of the elements of the necessity defense as apphed to civil disobedients posed constitutional problems. ${ }^{164}$ Professor Douglas Colbert has argued that the broad use of the motion in limine to preclude the necessity defense in pohtically sensitive cases runs afoul of the constitutional guarantees of the Fifth and Sixth Amendments. ${ }^{165}$ A successful prosecutorial in limine motion, like the per se rule set forth in Schoon, prevents the defendant froin presenting any proof regarding a given defense to the jury. Prior to Schoonand currently in other circuits-federal prosecutors have successfully einployed the motion in limine to prevent jury consideration of civil disobedients' necessity claims. ${ }^{166}$ Professor Colbert argues that such use violates these defendants' right to present fully their defenses to the jury. ${ }^{167}$ Precluding "an entire defense directly challenges the jury's role, as envisioned by the Franers of the Constitution, as a deinocratic body."168

This right to present a full defense is rooted in Supreme Court holdings emphasizing the fundamental nature of that right. In Chambers $v$. Mississippi, ${ }^{169}$ the Court recognized that "[t]he right of an accused in a criminal trial to due process is, in essence, the right to a fair opportumity to defend against the State's accusations." ${ }^{170}$ In Crane v. Kentucky, ${ }^{171}$

jury trial, the defendants' Sixth Amendinent rights were not at issue. However, because the Ninth Circuit created an absolute bar to the presentation of the necessity defense in cases of indirect civil disobedience, the Schoon holding imphicates the Sixth Amendment rights of future defendants who might otherwise have claimed necessity in their jury trials.

163. State v. Brechon, 352 N.W.2d 745, 751 (Minn. 1984) (reversing an appellate court's decision to exclude defendant's testimony regarding intent when trespassing on a munitions plant).

164. For a full examination of the constitutional imphications of excluding the necessity defense for civil disobedients, see Douglas L. Colbert, The Motion in Limine in Politically Sensitive Cases: Silencing the Defendant at Trial, 39 STAN. L. REv. 1271, 1316-26 (1987) (arguing that the constitutional right to be judged by a jury which has heard and considered a complete defense could be violated by excessive granting of prosecutors' motions in limine); Schulkind, supra note 31, at 8587 (discussing Supreme Court precedents assuring the right to present a criminal defense if evidentiary requirements are met).

165. Colbert, supra note 164 , at 1316-19.

166. Id. at $1295-97$.

167. Id. at 1317-27.

168. Id. at 1318 (footnote omitted).

169. 410 U.S. 284 (1973).

170. Id. at 294.

171. 476 U.S. 683 (1986) (holding that the exclusion of defendant's proffered evidence regarding the physical and psychological environment in which his confession was obtained violated either his Fourteenth Amendment due process rights or Sixth Amendment right to present a defense). 
the Court noted that "the Constitution guarantees criminal defendants 'a meaningful opportunity to present a complete defense." "172 The case for a constitutional right to present a defense is even stronger against a per se rule of exclusion than where the proffered defense is excluded by a motion in limine. In the latter case, the defendant will often be barred from raising the defense because the court rules it insufficient as a inatter of law. But in the former case, the defendant is not even allowed to raise the claim before the judge. No inatter how strong the defendant's clain inay be, it could never reach the jury.

\section{Policy Concerns and the Role of Jury}

Apart from the possible constitutional right to a necessity defense, strong policy arguments weigh in favor of permitting indirect civil disobedients to raise the defense. These arguments include those premised on the need to anplify individual viewpoints in today's bureaucratically run society, the social value of empowering the jury, and the goal of enhancing the quality and quantity of public discourse. These policy concerns are central to our vision of the democratic process, and raise critical questions about the role of civil disobedience in that systen. Yet Schoon failed to address these issues.

One line of argument in support of allowing the invocation of the necessity defense by civil disobedients considers the need to increase citizen participation in a society in which, as C. Wright Mills wrote, "The effective units of power are now the huge corporation, the inaccessible government, [and] the grim military establishment."173 The necessity defense proinotes participation by permitting individuals to present the defense in circuinstances in which their violation of law has been prompted by the failure of the ordinary legal chaimels of political debate. Granting a forum to the civil disobedient allows her views to be more widely disseminated. Simultaneously, it sends the inessage that our society highly values the pohtical input of the disobedient while recognizing the possibility that our denocratic system is capable of error. ${ }^{174}$

A second benefit of permitting the necessity defense for civil disobedients concerns its enhanceinent of the jury's role. The argument for jury empowerment is consistent with the broad powers conferred on the jury in the American legal tradition as the conscience of the coinmunity. Flexible rules allowing civil disobedients to present the necessity defense

172. Id. at 690 (quoting California v. Trombetta, 467 U.S. 479, 485 (1984)).

173. C. WRight Mills, THE POWER Elite 308-09 (1956), quoted in Bauer \& Eckerstrom, supra note 19 , at 1184 .

174. See Bauer \& Eckerstrom, supra note 19, at 1185. To the extent that a judicial system allows a defendant to argue that a particular law or governmental policy is wrong, it accepts the possibility that the democratic process is not flawless. By contrast, a judicial system that allows no room for questioning the products of the institutional democratic processes implicitly asserts that this process is incapable of error. 
provide the jury with the factual elements necessary to adequately render moral judgments. Even with flexible necessity rules, however, such jury empowerment would not be unlimited. First, the jury will ouly acquit when it is convinced that the defendant chose the lesser evil, after weighing the facts against the requirements of the defense. Second, a jury's pronounceinent on the guilt or innocence of a particular defendant does not invalidate a law. Like an acquittal based on any affirmative defense, the jury's verdict is limited to the particular circumstances of the case before it and is not an indictinent of the law under which the defendant is prosecuted. ${ }^{175}$

Permitting the necessity defense for civil disobedients may also indirectly foster the jury's role as a popular check on the administration of justice. By allowing civil disobedients to raise the defense, courts leave open the possibility of jury nullification, long recognized as essential to the sinooth operation of our justice systen. As legal scholar Roscoe Pound noted at the beginning of the century, "Jury lawlessness is the great corrective of law in its actual administration." 176 A per se rule barring the necessity defense not only prevents the jury froin returning a not guilty verdict in accordance with the law, but also effectively eliminates the possibility of jury nullification. Because a per se rule precludes adinission of any testimony regarding necessity, an indirect civil disobedient will be prevented froin explaining her conduct. The jury will hear only that evidence which relates to the eleinents of the crimie charged. ${ }^{177}$ As a result, the defendant cannot even hope for "jury lawlessness."

Toleration of the necessity defense also permits greater public discourse on the effectiveness of our political system generally, as well as on the particular issues raised by the civil disobedient. Pohtical necessity litigation sends a message to legislators by bringing the challenged law or policy into question. ${ }^{178}$ At the saine time, at least for the twelve jurors and other participants in the trial, it enhances the quantity and quality of their pohtical dialogue. Most critically, though, "the political necessity defense opens an avenue by which laws and lawmakers are held accountable to the people they serve, and an avenue by which people affirm and enforce their role as citizen-participants in the democratic process." 179

175. See id. at 1187 . Were large numbers of juries repeatedly to return acquittals, these verdicts could be taken to reflect popular discontent with the law challenged by civil disobedients. In such a case, the legislature would be well advised to question the law itself.

176. Roscoe Pound, Law in Books and Law in Action, 44 AM. L. Rev. 12, 18 (1910).

177. Contrast this with the situation in which a defendant's evidence on a defense fails to meet the minimum threshold necessary to obtain a jury charge. In such a case, the jury may still return a verdict of not guilty despite the fact that the prosecution proved every element of the charged offense beyond a reasonable doubt. See, e.g., Urited States v. Dougherty, 473 F.2d 1113, 1132 (D.C. Cir. 1972) (recognizing the "unreviewable and irreversible power in the jury, to acquit in disregard of the instructions on the law given by the trial judge").

178. See Bauer \& Eckerstrom, supra note 19 , at 1188 .

179. Id. at 1189. 
No matter how just a particular system may be, the possibility that it will produce unjust results always exists. Although permitting juries to evaluate claims of necessity may have soine costs, a per se rule refusing such consideration for a certain class of cases constitutes an implicit denial that our legal system can err. Such a demal can hardly be justified in a nation like ours, im which civil disobedience has been used to battle mjustice simce before the nation's very creation. From the Boston Tea Party to protests against slavery, ${ }^{180}$ and fron the civil rights movement to Vietnam War protests, civil disobedients-both direct and indirecthave influenced policymaking im the United States. ${ }^{181}$ The value of eivil disobedience as a grass roots response to institutional forces militates in favor of allowing the most democratic body in our legal systen, the jury, to decide questions of necessity.

\section{CONCLUSION}

This Note has argued that the Ninth Circuit opinion in United States v. Schoon misapplied the existing four-prong necessity test, and in the process created a per se rule that unnecessarily restricts civil disobedients' rights to invoke the necessity defense. The Schoon opinion may well be the coup de grace for civil disobedients seeking to argue necessity im the federal courts. As such, it necessarily provokes consideration of the role of civil disobedience and the availability of the necessity defense for civil disobedients from a more theoretical perspective. Ironically, it is precisely this perspective that the court failed to consider.

The court's interpretation of the four-prong test was restrictive and disingenuous. The Schoon court first mischaracterized the harm sought to be prevented as congressional policy, rather than as the death and suffering of El Salvadoran civilians. Next, with respect to the causal relationship prong, the court required a causal nexus so tight as realistically to exclude all civil disobedience. Lastly, the court adopted the rule that

180. Thoreau advocated protest of both slavery and the war of aggression against Mexico by the indirect means of refusal to pay taxes. In defense of his position, he offered the following justification:

Unjust laws exist: shall we be content to obey them, or shall we endeavor to amend them, and obey them until we have succeeded, or shall we transgress them at onee? Men generally, under such a government as this, think that they ought to wait until they have persuaded the majority to alter them. ... Why does [the government] not eneourage its citizens to be on the alert to point out its faults, and do better than it would have them? Why does it always crucify Christ, and excommunicate Copernicus and Luther, and pronounce Washington and Franklin rebels?

Henry D. Thoreau, Walden OR, Life in the Woods and on the Duty of Civil. DisOBEDIENCE 258 (1965).

181. "History abounds with examples of civil disobedience that have changed laws and policies." Bauer \& Eckerstrom, supra note 19, at 1181. Bauer and Eckerstrom cite the Boston Tea Party, the abolitionist inovement, the women's suffrage movement, the civil rights movement, and Vietnam era protests as examples of such success. Id. at $1181 \mathrm{n} .49$. 
the mere opportunity to petition Congress is enough to preclude the defense, regardless of the futility of such direct petitioning.

The consistent sentiment tying these rulings together may be an overreaching contempt for civil disobedients, who, in the court's view, were misusing the necessity defense. As the court wrote:

The real problem here is that hitigants are trying to distort to their purposes an age-old common law doctrine meant for a very different set of circumstances. What these cases are really about is gaining notoriety for a cause-the defense allows protestors to get their pohitical grievances discussed in a courtroom. ${ }^{182}$

The Schoon court's disdain for the idea of raising the grievances of civil disobedients in the courtroom, though, goes to the heart of the debate over the role of civil disobedience in our society. Although the court's reasoning im Schoon is flawed, the conclusion that the court reaches is not inherently unreasonable. At issue, though, are the values different participants bring to the civil disobedience debate. Opinions on the applicability of the defense $\mathrm{m}$ a given courtroom will necessarily be colored by opinions on the role of civil disobedience im general. Whether one beheves civil disobedients are malcontents or true democrats will necessarily influence how the elements of the necessity defense are construed.

In hight of the many benefits that civil disobedience and the flexible application of the necessity defense to civil disobedience cases would entail, the suspicion of federal courts, and the Schoon court im particular, seems unfounded. Future courts should examine more thoroughly than did the Schoon court the role of civil disobedience in our society when determining what legal standards to apply to civil disobedients, both direct and indirect, who raise the necessity defense.

182. Schoon, 971 F.2d at 199 (citing Bauer \& Eckerstrom, supra note 19, at 1176). 
